\title{
BONE MARROW MESENCHYMAL STEM CELLS PROTECT AGAINST FOLIC ACID- INDUCED ACUTE KIDNEY INJURY
}

\author{
Células-tronco mesenquimais protegem contra a lesão renal aguda induzida por ácido fólico
}

\author{
Marina Burgos-Silva1, Cassiano Donizetti-Oliveira', Marco Antonio Cenedeze', Denise Maria Avancini Costa Malheiros², Marlene Antônia \\ dos Reis ${ }^{3}$, Álvaro Pacheco-Silva', Patricia Semedo', Niels Olsen Saraiva Câmara ${ }^{1,4}$
}

\begin{abstract}
Acute kidney injury constitutes a syndrome responsible by a major percentage of acute kidney failures and it continues being associated to high mortality rates. Induced mainly by ischemia-reperfusion injury and nephrotoxic drugs, this condition is marked by a decrease in organ function and histopathological pattern of acute tubular necrosis. In search of more efficient therapies, a great deal of attention has been given to the therapeutic use of stem cells to treat kidney injuries. Bone marrow stem cells in particular have received a great attention due to its immunomodulatory properties, and its therapeutic mechanisms are intensely being studied in the literature. Purpose: In view of recent findings, the aim of our research was to get a better understanding on the potential role of bone marrow mesenchymal stem cells in a murine model of acute nephotoxicity induced by folic acid. Methods: C57 Bl/6j mice (8 weeks) were submitted to acute kidney injury by folic acid $(200 \mathrm{mg} / \mathrm{kg})$ administered intraperitoneally. After 24 hours, mice received mesenchymal stem cells $\left(5.10^{5}\right.$ cells per animal) through retro-orbital intravenous injection. Mice were sacrificed after 24 hours and blood and kidneys were harvested for analysis. Results: Stem cell treatment conferred functional improvement seen through lower creatinine and urea serum levels in 8 week old C57Bl/6j mice in comparison to mice treated only with folic acid (200mg/kg body weight). This amelioration are also correlated to down regulation of kidney pro-inflammatory cytokine mRNA levels as TNF-a, IL-6 and IL-1b in stem cell treated mice. In addition, treated mice demonstrated higher levels of immunostaining for proliferating cell nuclear antigen and a tendency towards a higher $\mathrm{Bcl}-2 / \mathrm{Bax} \mathrm{mRNA}$ ratio, indicating higher tissue regeneration and protection against injury-induced apoptosis. Conclusion: These results indicate bone marrow stem cells as an efficient tool in nephrotoxic kidney injury treatment.
\end{abstract}

Keywords: Acute Kidney Injury; Mesenchymal Stem Cells; Immunomodulation; Folic Acid.

\footnotetext{
Instituição:

${ }^{1}$ Experimental and Clinical Immunology Laboratory. Division of Nephrology. Federal University of São Paulo, São Paulo, São Paulo, Brazil;

${ }^{2}$ Pathology Department, University of São Paulo, São Paulo, Brazil;

${ }^{3}$ Pathology Department, UFTM, Uberaba, Minas Gerais, Brazil

${ }^{4}$ Laboratory of Transplantation Immunobiology, Department of Immunology, University of São Paulo, São Paulo, Brazil.
}

\section{Correspondência:}

Niels Olsen Saraiva Câmara, M.D.

Department of Immunology - Institute of Biomedical Science IV - USP

Rua Prof Lineu Prestes, 1730. 05508-900 São Paulo, SP, Brazil.

Phone: (5511) 3091-7388 Fax: (5511) 3091-7224

E-mail: niels@icb.usp.br

\section{INTRODUCTION}

Despite the advancements in replacement therapies and transplant research, acute kidney injury (AKI) is still associated to high hospital mortality rates (approximately $50 \%$ of all AKI patients in intensive care units), and a high index of consequent chronic kidney disease. ${ }^{1}$ Characterized by a rapid decline in the order of hours or weeks in the glomerular filtration rate and important acute tubular necrosis (ATN), immunologically, an expressive degree of tissue inflammation accompanies this functional impairment and amplifies organ tissue injury. In view of this, studies have long focused in immunoregulatory strategies to decrease kidney inflammation and restore organ homeostasis.

In the past two decades, especial attention has been given to particular therapeutic properties of stem cells. Defined according to its pluripotency and location of origin; along with its regenerative capacity, an important characteristic found in these cells has been its immunomodulatory ability. Many studies have demonstrated a special role for bone marrowderived mesenchymal stem cells (BMSC) in regulating injuries of inflammatory origin, mainly through paracrine pathways. ${ }^{2,3}$ 


\section{PURPOSE}

It has been shown that folic acid component, also known as Vitamin B9 widely used in dietary fortification, in large doses induces nephrotoxicity in murines, compromising renal function and inducing inflammatory kidney damage, ${ }^{4,5}$ making it an ideal model for the study of AKI. Therefore, our study aimed a better understanding on the potential role of the BMSC treatment in a mouse model of acute kidney nephrotoxicity induced by folic acid.

\section{METHODS}

\section{Animal model and sample preparation:}

Male C57BL/6j mice (8weeks) were obtained from CEDEME (Federal University of São Paulo, São Paulo, Brazil). All procedures were done following the UNIFESP Research Ethics Committee (CEP process no. 1164/2008). Animals received folic acid $(200 \mathrm{mg} / \mathrm{kg})$ in $\mathrm{NaHCO} 3(0.15 \mathrm{M})$ vehicle i.p. to induce acute kidney injury according to the protocol established by Klingler et al. At the determined time, animals were killed by anesthetic overdose, xilazine /ketamine (Agribands do Brasil Ltda, São Paulo) to obtain kidney and blood samples. Kidney fragments were snapped frozen in liquid nitrogen for gene expression assays or fixed in buffered formalin and embedded in paraffin for immunohistological assays. Blood samples were used for kidney functional analysis. Animals were divided into three groups, each with the respective sample number (unless where indicated otherwise): Ctr, exposed to no treatment $(n=3)$; FA, submitted to FA treatment and killed $48 \mathrm{~h}$ later $(\mathrm{n}=5)$; and FA+BMSC, which received BMSC 24 hours after FA treatment and which was killed 24 hours later $(n=5)$.

\section{Bone marrow-derived mesenchymal stem cells:}

Bone marrow stem cells were extracted from C57Bl/6 mice tibia and femur and cultivated in Dulbecco's Eagle medium low glucose (Cultilab) supplemented with $10 \%$ bovine fetal serum for $4-5$ passages at $5 \% \mathrm{CO} 2,37^{\circ} \mathrm{C}$. BMSCs were then characterized for the positive and negative expression of mesenchymal stem cell specific membrane markers (CD45, CD103, CD34 and MCHI) through flow cytometry, FACSCalibur flow cytometer (BD Biosciences). In parallel, BMSCs were also analyzed according to their adipogenic and osteogenic potential. BMSC adipogenesis was induced with low glucose DMEM medium supplemented with $10 \%$ FBS, dexamethasone $(1 \mu \mathrm{M})$, isobutylmethylxanthine $(0.5 \mathrm{mM})$, insulin $(10 \mu \mathrm{g} / \mathrm{ml})$, and indomethacin $(100 \mu \mathrm{M})$ for 14 days. Osteogenesis was achieved with low glucose DMEM supplemented with $10 \%$ FBS, dexamethasone $(0.1 \mu \mathrm{M})$, ascorbic acid $(0.2 \mathrm{mM})$, and beta glycerol phosphate $(10 \mathrm{mM})$ treatment for 28 days. Adipocyte lipid and osteocyte calcium deposit staining was done by Oil Red and Von Kossa, respectively. For BMSC treatment, cultivated BMSC were suspended in sterile phosphate buffered saline (PBS) and administered unto C57Bl/6 anesthetized mice $\left(5.10^{5}\right.$ cells) through retro-orbital intravenous injection.

\section{Kidney function assays:}

Serum creatinine and urea measurements were performed through colorimetric assays based on the Jaffe and urease methods using deproteinized serum samples (Labtest, São Paulo, Brazil). Values were determined using a spectrophotometer and analyzed accordingly.

\section{Gene expression assays:}

a) RNA isolation: In brief, total RNA was extracted from snap frozen kidney fragments using Trizol Reagent ${ }^{\circledR}$ (Invitrogen, Carlsbad, CA, USA), and isolated using cloroform and isopropanol solutions; b) Single strand cDNA synthesis was performed using MML-V reverse transcriptase (Promega, Madison, USA). c) RT-PCR: Reverse transcriptase polymerase chain reaction (RT-PCR) was performed using TaqMan primers (Applied Biosystem, USA) for the following molecules: TNF- $\alpha$ (Mm00443258_m1), IL-6 (00561420_m1), IL-1ß (Mm01336189_ m1) Bax (Mm00432050_m1) and Bcl-2 (Mm00477631). The Sequence Detection Software 1.9 (SDS) was used for the analysis, and mRNA expression was normalized to HPRT values. The values are expressed relative to a reference from the control samples. The Ct (threshold cycle) for the target gene and the $\mathrm{Ct}$ for the internal control were determined for each sample. Samples were run in triplicate. The relative expression of $\mathrm{mRNA}$ was calculated by $2-\Delta \Delta \mathrm{CT}$. All the experimental samples are expressed as an $\mathrm{n}$-fold difference relative to the calibrator.

\section{Acute Tubular Necrosis (ATN):}

HE-stained kidney histological sections were assessed for acute tubular necrosis and tissue regeneration and ranked according to the percentage of area affected.

\section{Kidney cell mitosis:}

In order to assess kidney regeneration, paraffin-embedded sections were submitted to immunohistochemistry after heat retrieval and stained for Proliferating cell nuclear antigen (PCNA) (diluted 1:200; clone PC10, DAKO), using a HRPconjugated secondary antibody (Horseradish peroxidase), EnVision $^{\text {tw }}+$ Dual Link System-HRP (Dako, EUA) revealed with 3.3'-diaminobenzidine $(\mathrm{DAB})+$ substrate-chromogen (Dako, EUA).

Statistic analysis: Data used was expressed as mean \pm S.D. Differences between groups were evaluated for statistical significance using ANOVA followed by the Bonferroni test and Student's t-test. Differences were considered significant at $\mathrm{P}<$ 0.05 .

\section{RESULTS}

\section{Kidney Function and ATN:}

In order to evaluate AKI in FA-induced nephropathy, doseresponse and time-response curves were established through kidney function analyses (data not shown). Serum creatinine and urea levels showed efficient kidney damage in FA-treated mice at $200 \mathrm{mg} / \mathrm{kg}$ body weight and functional impairment peaked $48 \mathrm{~h}$ after drug injection (data not shown). These references were therefore used for stem cell treatment evaluation. Initial function assays demonstrated that BMSC treatment $24 \mathrm{~h}$ after AKI induction (FA+BMSC) conferred significant protection $(p<0.05)$ in kidney function in comparison to folic acid only 
(FA) -treated mice (Fig.1A). This amelioration also were correlated to a tendency towards lower ATN scores, as assessed by histopathological analyses (Fig.1B,C).

Figure 1. Kidney function and histomorphology 48h after FA (200mg/ $\mathrm{kg}$ ) or vehicle (NaHCO3 0,15M) injection; A) Serum creatinine and urea values for ctr, FA, and FA+BMSC-treated animals; Data expressed as mean of $\mathrm{mg} / \mathrm{dL} \pm S D B$ ) Representative image for a) $\mathrm{ctr}, b) \mathrm{FA}$, and c) FA+BMSC-treated animals, magnification 40x. C) Tissue necrosis and repair scores found in kidneys (ctr, $n=2$; FA and $F A+B M S C, n=3$ ), expressed as mean of the percentage of affected areas per field evaluated $\pm S D . \quad \# p<0.05$ vs. ctr, $\# \# p<0.005$ vs. $c t r,{ }^{*} p<0.05$ vs. FA.

$$
\text { A }
$$

B
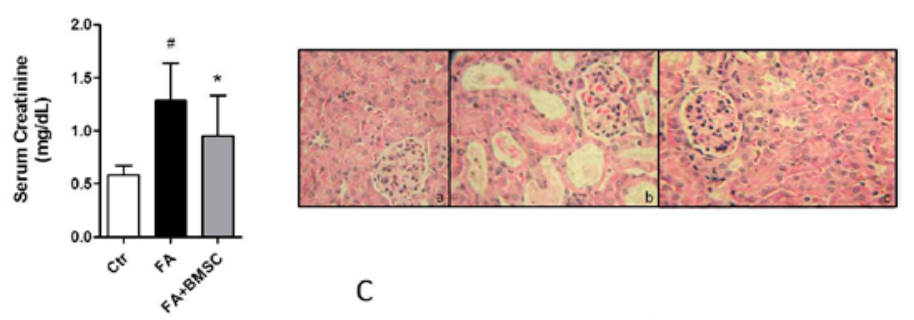

C
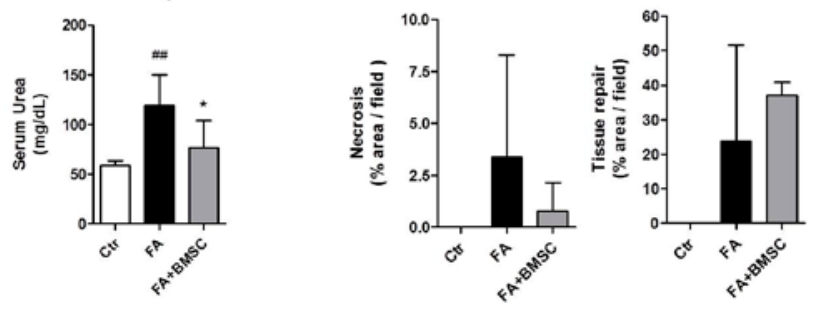

\section{Immunomodulation:}

In order to elucidate the mechanism through which BMSCs exerted their therapeutic effects, our group studied a possible immunomodulatory role for these cells through RT-PCR gene expression for classical inflammatory pathways. While the FA group developed a significant pro-inflammatory profile indicated by significantly higher levels of TNF-a, IL-6 and a tendency towards higher IL-1b mRNA expression, BMSC-treated animals displayed a reduction in the levels of these components, with a tendency towards lower TNF-a mRNA expression indicating a decrease in tissue inflammation for BMSC-treated mice (Fig. 2).

Figure 2. Tissue proinflammatory $m R N A$ profile. TNF $\alpha, I L-6$ and $I L-1 \beta$ kidney mRNA expression, evaluated through RT-PCR and generated by referencing each gene to HPRT (hypoxanthine-guanine phosphoribosyltransferase - housekeeping gene) as an internal control (ctr, $n=3$; FA and $F A+B M S C, n=3$ ). Data expressed as the mean of $2-\Delta \Delta C t \pm S D . \# p<0.05$ vs. $c t r,{ }^{*} p<0.05$ vs. $A F$.
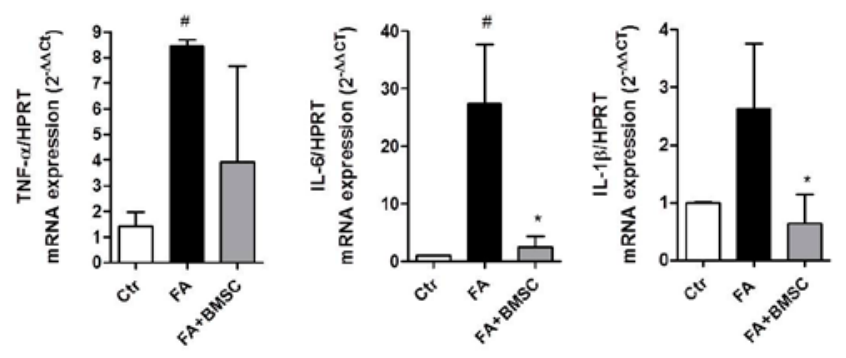

Tissue regeneration:

Another mechanism of action postulated for MSC therapy consists in its regenerative properties. This phenomenon was assessed by immunohistochemistry staining for PCNA, which denotes mitotic cells. Positive staining confirmed this theory, as the AF+BMSC group displayed higher levels of mitotic cells when compared to the FA group (Fig. 3). In parallel, our group also assessed the tissue's anti-apoptotic index indicated by a Bcl-2/Bax mRNA ratio. FA-treated mice had an important tendency towards a lower anti-apoptotic index. In comparison, this tendency was reversed in the stem cell-treated group which displayed a Bcl-2/Bax mRNA ratio, similar to the control group, which were also correlated to PCNA mitosis results.

Figure 3. Kidney cell proliferative and apoptotic profile evaluation. A) Immunhistochemistry for PCNA. Representative image for a) ctr, b) $F A$, and c) $F A+B M S C$-treated animals. Full arrows indicate positive staining. Magnification 20x. B) (Bcl-2/ Bax) kidney mRNA expression evaluated through RT-PCR and generated by referencing each gene to HPRT as an internal control (ctr, $n=2 ; F A$ and $F A+B M S C, n=4)$. Data expressed as the mean of $2-\Delta \Delta C t \pm S D$.

A

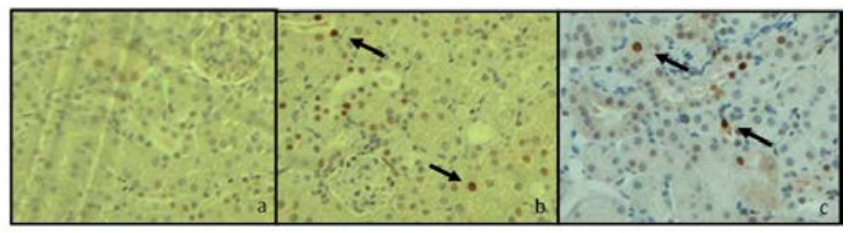

B

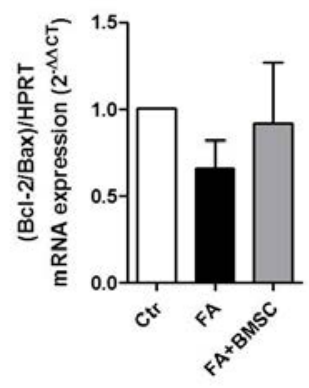

\section{DISCUSSION}

Despite recent advances in the treatment of acute nephropathies, AKI continues to burden hospitals with high mortality rates and patient therapy costs. In search for more efficient therapies, increased interest has appeared in cell therapies towards the treatment of acute kidney diseases.

Mesenchymal stem cells (MSC) are progenitor cells found in a diversityofregionslikeblood, bonemarrow, umbilicalcord, dental pulp and adipose tissue. ${ }^{6}$ They possess considerable capacity for autorenovation and cellular differentiation. In addition, MSC are known for their important immunomodulatory properties, ${ }^{2}$ possessing modulatory functions in vitro and in vivo, and therefore, being studied extensively as therapeutic tools in mediating pathologies of inflammatory origin.

FA also known as vitamin B9 is traditionally used in dietary fortification, prevention of prenatal neural development abnomalies and treatment of anemia and other pathologies such 
as Alzheimer and Parkinson., ${ }^{7,8}$ Despite these effects, high doses of FA are known by inducing a significant kidney damage in mice and it has been used extensively as an experimental model of drug-induced nephropathy. ${ }^{4,5}$

Initial results showed that BMSC treatment was efficient in mediating FA- induced kidney function impairment, as demonstrated by reduced serum urea and creatinine levels. This protection was corroborated by histopathology analyses which indicated lower scores of ATN and higher levels of tissue repair. These results confirm the protective functional benefits also seen in the stem cell treatment of other nephrotoxic injuries. 9,10 There are many mechanisms through which MSC mediate injury amelioration. One possibility suggests that transdifferentiation or stem cell fusion ${ }^{11,12}$ would allow the injury protection through the substitution/recovery of damaged cells. However, this phenomenon is rarely described in kidneys with studies involving stem cell treatment, and its actual contribution in injury protection is highly questionable. ${ }^{9,13}$ In search to clarify the mechanism for the BMSCs-mediated protection of FA nephropathy, our group focused in stem cell's paracrine immunomodulatory properties. Because increased amounts of inflammatory mediators activate the immune system and consequently amplifying tissue oxidative stress and secondary tissue injury, a controlled inflammatory process is considered beneficial and it is the aim of most therapies involving tissue injury. RT-PCR experiments showed a lower proinflammatory profile in kidneys of BMSC-treated animals, seen by decreased levels of TNF-a, IL- 6 and IL-1b mRNA in comparison to animals treated only with FA. This indicated that MSC protected kidneys by partially regulating tissue inflammation, and it has confirmed other studies which also describe a decrease in the expression of proinflammatory molecules after MSC treatment. ${ }^{3,14}$ Our study also showed that BMSC treatment increased kidney cell turnover. Since the cell death is a common characteristic for acute kidney injury, 15 higher proliferation rates induced by BMSC increase the turnover of injured cells to healthy ones, and consequently help to restore tissue homeostasis., ${ }^{3,16}$ Therefore, our results also indicate that BMSC may accelerate tissue repairing through an increase in cell turnover.

\section{CONCLUSION}

In summary, our study found a protective role for BMSC treatment over folic acid-induced acute kidney injury. This therapy is correlated to kidney function and tissue structure preservation. These findings also correlated with a reduction in inflammatory mRNA, which indicates an immunomodulatory action and stimulates tissue regeneration. Therefore, we have concluded that BMSC treatment is a promising tool towards nephrotoxic acute kidney injury, and should be studied in view of future clinical use.

\section{RESUMO}

A insuficiência renal aguda (IRA) constitui uma síndrome responsável por grande parte das falências renais agudas e continua hoje associada a um alto índice de mortalidade. Desencadeada principalmente por processos de isquemia e reperfusão no órgão e drogas nefrotóxicas, essa síndrome é caracterizada fisiologicamente por uma perda repentina da função do órgão e dano estrutural histológico denominado necrose tubular aguda. Diante da busca por terapias mais eficazes, tem-se focado intensamente na possibilidade do uso de células-tronco na lesão renal. As células-tronco mesenquimais derivadas de medula óssea, em especial, têm recebido grande atenção devido às suas propriedades imunomoduladoras, e seus mecanismos terapêuticos estão sendo intensamente estudados na literatura. Objetivo: Em vista de estudos recentes, nosso trabalho buscou maior compreensão sobre o papel das célulastronco mesenquimais derivadas de medula óssea em um modelo murino de lesão renal aguda induzida por ácido fólico. Métodos: Camundongos C57Bl/6 (oito semanas) foram submetidos a lesão renal aguda por ácido fólico (200mg/kg de massa corporal) administrado intraperitonealmente. Após 24 horas, os animais receberam células-tronco mesenquimais (5.10 células por animal) via injeção intravenosa pelo plexo retro-orbital. Os animais foram sacrificados após 24 horas e amostras de sangue e rins foram colhidas para análise. Resultados: Os animais tratados com células apresentaram melhora funcional representada pela redução dos níveis de creatinina e uréia sérica em camundongos $\mathrm{C} 57 \mathrm{Bl} / 6 \mathrm{j}$, em comparação a animais tratados somente com $\mathrm{AF}$. Esses dados correlacionamse com a menor expressão do RNAm de citocinas pró-inflamatórias tais como TNF-a ,IL-6 e IL-1b nos rins dos animais tratados com células. Ainda, os animais tratados com células demonstraram níveis de proliferação celular por imunohistoquímica de PCNA e tendência a uma maior razão de mRNA de $\mathrm{Bcl} 2 / \mathrm{Bax}$, indicando maiores índices de regeneração tecidual e proteção contra apoptose induzida por lesão. Conclusão: Esses resultados indicam que as células-tronco mesenquimais derivadas de medula óssea são uma ferramenta importante no tratamento à lesão renal nefrotóxica.

Descritores: Lesão Renal Aguda; Células-Tronco Mesenquimais; Imunomodulação; Ácido Fólico. 


\section{REFERÊNCIAS:}

1. Mehta RL, Pascual MT, Soroko S, Savage BR, Himmelfarb J, Ikizler TA, et al. Spectrum of acute renal failure in the intensive care unit: the PICARD experience. Kidney Int. 2004 Oct;66(4):1613-21.

2. Stagg J. Immune regulation by mesenchymal stem cells: two sides to the coin. Tissue Antigens. 2007 Jan;69(1):1-9.

3. Togel F, Hu Z, Weiss K, Isaac J, Lange C, Westenfelder C. Administered mesenchymal stem cells protect against ischemic acute renal failure through differentiation-independent mechanisms. Am J Physiol Renal Physiol. 2005 Jul;289(1):F31-42.

4. Szczypka MS, Westover AJ, Clouthier SG, Ferrara JL, Humes HD. Rare incorporation of bone marrow-derived cells into kidney after folic acidinduced injury. Stem Cells. 2005;23(1):44-54.

5. Wan B, Hao L, Qiu Y, Sun Z, Cao Q, Zhang Y, et al. Blocking tumor necrosis factor-alpha inhibits folic acid-induced acute renal failure. Exp Mol Pathol. 2006 Dec;81(3):211-6.

6. Meirelles Lda S, Nardi NB. Methodology, biology and clinical applications of mesenchymal stem cells. Front Biosci. 2009;14:4281-98.

7. Kronenberg G, Colla M, Endres M. Folic acid, neurodegenerative and neuropsychiatric disease. Curr Mol Med. 2009 Apr;9(3):315-23.

8. Muller T. Role of homocysteine in the treatment of Parkinson's disease. Expert Rev Neurother. 2008 Jun;8(6):957-67.

9. Kim JH, Park DJ, Yun JC, Jung MH, Yeo HD, Kim HJ, et al. Human adipose tissue-derived mesenchymal stem cells protect kidneys from cisplatin nephrotoxicity in rats. Am J Physiol Renal Physiol. 2012 May;302(9):F1141-50.
10. Hauser PV, De Fazio R, Bruno S, Sdei S, Grange C, Bussolati B, et al. Stem cells derived from human amniotic fluid contribute to acute kidney injury recovery. Am J Pathol. 2010 Oct;177(4):2011-21.

11. Strassburg S, Hodson NW, Hill PI, Richardson SM, Hoyland JA. Bidirectional exchange of membrane components occurs during co-culture of mesenchymal stem cells and nucleus pulposus cells. PLoS One. 2012 Mar 15;7(3):e33739.

12. Beitnes JO, Oie E, Shahdadfar A, Karlsen T, Muller RM, Aakhus S, et al. Intramyocardial injections of human mesenchymal stem cells following acute myocardial infarction modulate scar formation and improve left ventricular function. Cell Transplant. 2012;21(8):1697-709

13. Fang TC, Alison MR, Cook HT, Jeffery R, Wright NA, Poulsom R. Proliferation of bone marrow-derived cells contributes to regeneration after folic acid-induced acute tubular injury. J Am Soc Nephrol. 2005 Jun;16(6):1723-32.

14. Humphreys BD, Bonventre JV. Mesenchymal stem cells in acute kidney injury. Annu Rev Med. 2008;59:311-25.

15. Zhou D, Li Y, Lin L, Zhou L, Igarashi P, Liu Y. Tubule-specific ablation of endogenous beta-catenin aggravates acute kidney injury in mice. Kidney Int. 2012 Sep;82(5):537-47

16. Cantaluppi V, Gatti S, Medica D, Figliolini F, Bruno S, Deregibus MC, et al. Microvesicles derived from endothelial progenitor cells protect the kidney from ischemia-reperfusion injury by microRNA-dependent reprogramming of resident renal cells. Kidney Int. 2012 Aug;82(4):412-27 